JURNALYOGA DAN KESEHATAN

JURUSAN YOGA KESEHATAN

FAKULTAS BRAHMA WIDYA

IHDN DENPASAR
Vol. 3 No. 2 September 2020

ISSN : 2621-0185 (Cetak)

ISSN : 2722-9440 (Online)

http://ejournal.ihdn.ac.id/index.php/jyk

\title{
Yoga Asanas: Lifestyle Kesehatan di Masa New Normal
}

\author{
I Nyoman Subrata \\ Institut Hindu Dharma Negeri Denpasar \\ email : inym.subrata@gmail.com
}

Diterima tanggal 10 Agustus 2020, diseleksi tanggal 16 Agustus 2020, dan disetujui tanggal 29 Agustus 2020

\section{ABSTRACT}

This research examines the application of yoga asanas in a new level of life (new normal) during the Covid-19 virus pandemic. The discourse about the Covid-19 outbreak directs humans to be able to live healthy lives. Health is an important benchmark in the transition period to keep the body healthy during activities. Within this framework, this study uses a qualitative descriptive research method that is described using a socio-religious approach. Due to the phenomenon that occurs in society, activities that are rarely outside the home make a healthy lifestyle so important. A healthy lifestyle by applying the practice of yoga asanas during work from home is a choice for some people to make rhythm adjustments in activities in a productive way and balanced with nutritious food and drinks. Yoga asanas in physical distancing situations certainly have many benefits to support body health. Not only as a lifestyle or a healthy lifestyle, but yoga asanas has now become the most important part of implementing the natural health of the human body to increase immunity, maintain body stability, increase concentration, control thoughts, prevent depression, and even reduce stress management in the current new normal.

Keywords: yoga asanas; lifestyle; health; new normal

\section{ABSTRAK}

Penelitian ini mengkaji tentang penerapan yoga asanas dalam tataran kehidupan baru (new normal) di tengah maraknya pandemi virus Covid-19. Diskursus tentang adanya wabah Covid-19 mengarahkan manusia untuk dapat berperilaku hidup sehat. Kesehatan merupakan tolak ukur penting di masa transisi guna menjadikan tubuh selalu sehat selama beraktivitas. Dalam kerangka pemikiran tersebut, penelitian ini menggunakan metode penelitian deskriptif kualitatif yang dijabarkan menggunakan pendekatan sosio-religius. Atas fenomena yang terjadi di tengah masyarakat, aktivitas yang jarang di luar rumah menjadikan pola hidup sehat menjadi begitu penting. Gaya hidup sehat dengan menerapkan praktik yoga asanas selama work from home menjadi pilihan alternatif bagi sejumlah orang untuk melakukan penyesuaian ritme dalam aktivitas-aktivitas dengan cara produktif dan diimbangi dengan makanan dan minuman yang bernutrisi. Yoga asanas dalam situasi physical distancing tentu memiliki banyak manfaat untuk menunjang kesehatan tubuh. Bukan hanya sebagai lifestyle atau gaya hidup sehat, tetapi yoga asanas kini menjadi bagian terpenting sebagai penerapan kesehatan alami tubuh manusia untuk meningkatkan imun, menjaga kestabilan tubuh, meningkatkan konsentrasi, pengendalian pikiran, pencegahan depresi bahkan mengurangi stress management di masa new normal saat ini.

Kata kunci: yoga asanas, lifestyle, kesehatan, new normal 


\section{PENDAHULUAN}

Fenomena yang terjadi di negara Indonesia sementara ini dihentikan akibat terjadinya penyebaran virus corona. Menurut World Health Organization (WHO), bahwa virus corona dapat menginfeksi pada sistem pernafasan yang dapat di identifikasi seperti penyakit flu biasa sampai penyakit pernafasan yang semakin parah. Virus corona atau Covid-19 dapat ditularkan antara hewan dan manusia. Berdasarkan Kementerian Kesehatan Indonesia yang dikutip oleh Hanoatubun (2020) bahwa Covid-19 telah ada di Wuhan Municipal Health Committee pada tanggal 30 Desember 2019 sampai tersebar ke 188 negara yang terkonfirmasi kena virus Corona. Penyebaran virus Corona ini menyebabkan berbagai belahan dunia mengalami dampak yang sangat besar pada perekonomian negara, perdagangan, investasi bahkan pariwisata.

Kini pada aktivitas manusia yang biasanya semakin padat dan cenderung tidak memiliki waktu luang yang mengakibatkan setiap manusia sangat dibatasi oleh ruang dan waktu bahkan kesempatan untuk berkomunikasi pun tidak ada sama sekali. Apalagi diiringi juga dengan padatnya rutinitas keseharian dalam bekerja atau aktivitas lainnya. Hal ini menyebabkan setiap orang mengalami pergeseran terhadap lifestyle atau gaya hidup manusia saat ini. Bilamana di awal bulan Maret 2020 negara Indonesia tiba-tiba mengalami masa transisi terhadap dampak penyebaran penyakit virus Corona (Covid-19). Situasi ini menyebabkan semua aktivitas manusia sementara dihentikan dan semua pekerjaan dialihkan melalui tatap muka atau daring lewat rumah (work from home).

Selama berada di rumah aktivitas yang dilakukan oleh setiap orang yang berada pada profesi pengajar, pengusaha, dan lain sebagainya, kebanyakan memberikan materi, presentasi dan komunikasi lewat media teleconference atau daring menggunakan aplikasi whatsapp, zoom, skype dan lain sebagainya sebagai pendukung dalam berkomunikasi. Keadaan yang berada di rumah selama beberapa bulan ini, membuat setiap manusia mengalami kejenuhan pikiran, kebosanan, ketidaknyamanan, stress bahkan depresi kepanjangan akibat tidak diperbolehkan keluar dari rumah, tidak memiliki pekerjaan atau kena PHK serta permasalahan keuangan yang semakin menipis walau telah ada subsidi dari pemerintah, tetap masyarakat mengalami kekurangan terhadap keuangan tersebut.

Sementara, untuk mengendalikan yang terjadi di masa new normal masyarakat perlu membiasakan diri dalam situasi yang terjadi saat ini. Dengan cara mengalihkan pikiran menuju hal-hal yang positif yang mampu mengantarkan energi positif pada diri sendiri bahkan di dalam keluarga itu sendiri. Teknik yang dapat memberikan suasana yang nyaman bagi setiap manusia sebagai lifestyle di masa new normal yakni dengan melakukan praktik yoga asanas. Menurut Utama (2018: 16) mengungkapkan bahwa tren praktik yoga asanas saat ini sedang mulai menuju 
(lifestyle) gaya hidup sehat. Transformasi ini perlu didukung dengan aktivitas olah tubuh yang baik serta makanan dan minuman sehat yang bernutrisi. Berdasarkan temuan dari Juniartha (2019: 85) bahwa, perlu adanya penyesuaian ritme aktivitas, agar ketegangan tubuh dan kelelahan fisik, mental dan jiwa karena banyaknya aktivitas yang dilakukan di dalam rumah. Untuk itu diperlukan sebuah olah tubuh manusia yang dapat dipraktekan secara sederhana, mengefisienkan waktu dan meningkatkan kesehatan jasmani dan rohani melalui praktik yoga.

Praktik yoga sebenarnya telah melampaui seluruh kegiatan olah tubuh, karena yoga memiliki kelengkapan trilogi ilmu pengetahuan yakni dari hakikat dan realita ontologi, cara berpikir pengetahuan epistemologi yang tersistematis dan nilai aksiologi sebagai pelengkap makna dari yoga. Yoga berarti pengalaman dari keutuhan atau kesatuan dengan keberadaan batin. Kesatuan ini hadir setelah menghancurkan dualitas pikiran ke dalam kesadaran tertinggi. Asana, pranayama, mudra dan bandha adalah empat kajian utama dari yoga. Keempat unsur tersebut tidak dapat dipisahkan, saling berhubungan dan berkaitan antara satu dengan lainnya. Asana merupakan langkah ketiga dalam delapan tahapan jalan yoga, yang dikenal dengan sebutan astangga yoga atau delapan tahapan yoga. Tujuannya adalah membuat tubuh menjadi mantap dan siap untuk melakukan teknik-teknik yang lebih tinggi seperti pranayama (pengaturan nafas), pratyahara (penarikan indera), dharana (konsentrasi), dhyana (meditasi) dan Samadhi (realisasi kosmis). Secara bertahap, setelah tubuh menjadi terbiasa terhadap latihan asanas yang lentur dan santai, maka semua aktivitas fisik akan menjadi bagian dari asanas, dilakukan dengan lancar, halus, disertai dengan nafas yang dalam sehingga tubuh mendapat banyak oksigen dan pikiran menjadi tenang dan terkendali serta tanggap terhadap berbagai kebutuhan dan situasi (Sena, 2018:16).

Berkaitan dengan yoga, tentunya ada beberapa orang menyebutkan bahwa yoga asanas dijadikan sebagai lifestyle kesehatan di masa new normal. Menurut Utama (2018: 20-21), Tidak hanya berposisi pada new normal dalam masa-masa pandemi ini. Banyak orang lebih memperhatikan kesehatannya dengan melakukan berjogging, naik sepeda, olahraga secara kecilkecilan, dan lain sebagainya bahkan yoga asanas pun dijadikan sebagai treatment untuk menjaga kesehatan tubuh manusia dari fisik dan mental. Jika dikaitkan dengan tingginya minat kelas menengah urban dalam mengikuti praktik yoga, bahwa praktik yoga asanas tidak hanya dipahami sebagai ajaran dalam memasuki dunia spiritualitas, melakukan penyatuan dengan ilahi, melainkan dimaknai sebagai kode dan aktivitas simbolik untuk menunjukkan identitas diri mereka di masyarakat. Dalam artian motivasi orang mengikuti yoga memang cenderung pada hal-hal yang pragmatis, yang salah satunya adalah menunjukkan daya konsumsi dan gaya hidup (lifestyle). Olehnya, penelitian ini memfokuskan pada kajian interpretatif terhadap yoga asanas 
di tengah masa transisi new normal akibat Covid-19. Yoga asanas menurut beberapa penelitian terdahulu memiliki manfaat bagi kesehatan tubuh. Selain itu, yoga asanas saat ini sangat cocok diterapkan dalam situasi physical distancing.

\section{PEMBAHASAN}

\subsection{Yoga Asanas Sebagai Lifestyle Kesehatan Tubuh Manusia}

Lifestyle merupakan salah satu aspek yang esensial yang ada di era modern saat ini yang biasanya disebut dengan gaya hidup manusia. Gaya hidup merupakan gambaran bagi setiap orang yang mengenakannya dan menggambarkan seberapa besar perilaku seseorang di dalam masyarakat. Selain itu, gaya hidup juga dapat diartikan sebagai suatu seni yang dibudidayakan oleh setiap orang. Gaya hidup yang dijalani dapat menentukan kualitas hidup dan kesehatan tubuh. Seseorang yang memiliki gaya hidup yang positif dan pola hidup yang sehat cenderung memiliki kualitas hidup yang lebih memadai, begitu juga sebaliknya (Kurniadi, 2008).

Sementara itu, gaya hidup dapat ditentukan oleh salah satu indikator kualitas hidup seseorang. Seseorang yang memiliki gaya hidup sehat akan menjalankan kehidupannya dengan memperhatikan faktor-faktor yang mempengaruhi kesehatan seperti makanan, pikiran, kebiasaan olahraga, dan lingkungan yang sehat. Hal ini akan menyebabkan tingkat kesehatan seseorang menjadi baik. Kesehatan yang baik menjadikan kualitas hidup seseorang meningkat (Anne, 2010). Sebaliknya, perubahan gaya hidup ke arah tidak sehat seperti konsumsi makanan instan, kurang berolahraga, perilaku merokok, pengendalian stres yang buruk, dan lingkungan yang tidak sehat akan memperburuk kondisi kesehatan. Seseorang dengan gaya hidup tidak sehat akan mudah terkena penyakit seperti penyakit jantung, diabetes melitus, bahkan stroke yang mana kondisi ini menjadikan kualitas seseorang menjadi menurun (Cahyono, 2012). Untuk mencapai kualitas kesehatan, maka diperlukan pembentukan faktor yang dapat mempengaruhi kualitas internal dan eksternal manusia. Faktor internal mencakup aspek fisik seperti kesehatan organ tubuh, aspek psikis misalnya emosional \& motivasi, dan aspek sosial misalnya kemampuan bersosialisasi dengan lingkungan. Sedangkan faktor eksternal mencakup tempat belajar, suasana lingkungan dan budaya belajar (Anni, 2004).

Berdasarkan hal tersebut, lifestyle yang dapat digunakan sebagai pembentukan faktor produktif yang dapat meningkatkan konsentrasi kesehatan tubuh manusia dengan praktekpraktek disiplin untuk mencapai kesadaran jiwa manusia itu sendiri yakni menggunakan metode Yoga dalam usaha mencapai kesadaran jiwa. Kesadaran jiwa dimaksud adalah kesadaran akan kesejatian diri yang dilakukan dengan penyatuan tubuh, pikiran dan jiwa, yang tentunya dilakukan dengan praktek-praktek disiplin olah tubuh dan pikiran. Hal ini sangat sulit untuk 
dilakukan jika tidak disertai dengan disiplin (sadhana) dan kebiasaan (abhyasa). Kebiasaan dan disiplin dapat membantu dan melatih tubuh, pikiran dan jiwa untuk bergerak seirama dan senada sehingga menghasilkan tubuh yang harmoni (Sena, 2018:16).

Ditinjau dari sains, yoga juga terdapat bentuk asanas yang dapat mempengaruhi dari setiap aspek fisik manusia, tidak saja membuat seimbang kerja kelenjar tetapi juga membuat otot-otot giat dan santai, begitu pula dengan sistem saraf, menstimulasi sirkulasi, mengendurkan otot dan memusatkan pikiran. Selama melakukan gerakan-gerakan yang halus ini, tubuh tetap berada dalam keadaan efisien yang rileks dan pernapasan panjang yang menyertai sikap-sikap ini membuat darah menyerap lebih banyak oksigen. Selama melakukan asanas, tenaga lebih banyak dikumpulkan daripada dikeluarkan. Asanas, sebagai kebalikan dari olahraga yang selama ini ada melibatkan kontraksi otot tertentu, dipertahankan dalam jangka waktu tertentu dan diikuti oleh perasaan yang rileks dan nafas yang halus. Setelah melakukan gerakan asanas yang cukup lama, maka otot-otot akan menjadi rileks. Dengan kata lain, melalui asanas kita mendapatkan secara alami apa yang tidak pernah diberikan oleh obat-obatan yakni membuat rileks otot. Relaksasi yang sempurna dari gerakan asanas dapat menghemat energi yang dapat dikumpulkan oleh tubuh untuk meningkatkan pikiran mencapai kesadaran kosmis (Sena, 2018:16).

Melalui yoga asanas, akan membentuk suatu sistem kesehatan dan menstimulasikan sirkulasi pada peredaran darah tubuh manusia. Hal ini mampu memberikan dampak kesehatan yang baik dalam menjaga imunitas atau ketahanan tubuh manusia dari berbagai penyakit berbahaya termasuk masalah virus corona yang sampai sekarang masih dalam situasi cukup memprihatinkan seluruh masyarakat Indonesia akibat dampak yang ditimbulkan. Untuk menjaga kesehatan dan tetap dalam situasi tubuh yang segar, sehat dan kuat di masa new normal ini. Maka perlu yang namanya gerakan yoga asanas yang sangat sederhana tetapi dapat menjaga kesehatan tubuh dan terhindarnya dari berbagai penyakit berbahaya.

\subsection{Teknik Yoga Asanas Dalam Menjaga Ketahanan Tubuh di Masa New Normal}

Yoga telah dikenal sebagai sistem filosofi kehidupan masyarakat India kuno (Sindhu, 2007, Stiles, 2002). Saat ini, yoga telah berkembang menjadi salah satu sistem kesehatan yang komprehensif dan menyeluruh. Teknik yoga klasik dikembangkan oleh Patanjali melalui Kitab Yoga Sutra (Stiles, 2002). Istilah yoga berasal dari kata Yuj dan Yoking dalam bahasa Sansekerta yang bermakna penyatuan secara harmonis dari yang terpisah (Sindhu, 2007; Stiles, 2002). Maksud dari penyatuan secara harmonis tersebut adalah proses menyatukan antara tubuh, pikiran, perasaan dan aspek spiritual dalam diri manusia (Stiles, 2002). Terdapat dua pandangan yang membahas tentang konsep latihan yoga. Pandangan yoga klasik fokus di aktivitas yang 187 | YOGA DAN KESEHATAN Vol. 3 No. 2, September 2020 
mengembangkan insight untuk memahami kebenaran mengenai diri manusia sedang pandangan hatha yoga fokus di aktivitas yang mengembangkan kesehatan fisik dan psikologis (Stiles, 2002). Untuk mendapat hasil yang maksimal secara fisik, psikologis dan spiritual, orang yang melakukan yoga dianjurkan untuk berlatih dengan dua konsep tersebut (Stiles, 2002). Yoga dapat dilakukan oleh semua kalangan dari anak-anak hingga lanjut usia. Yoga sangat mudah dilakukan dan bukan latihan yang terkait dengan agama tertentu. Patanjali (Stiles, 2003) menyebutkan bahwa yoga bukan merupakan agama dan setiap orang sesungguhnya melakukan yoga. Setiap orang melakukan yoga karena sesuai dengan tujuan yoga, yaitu untuk mendapat kebahagiaan yang sebenarnya dapat diperoleh melalui proses kesadaran terhadap diri. Selama ini manusia belum sepenuhnya menyadari bahwa kebahagiaan diperoleh dari menyadari diri sendiri. Manusia merasa bahwa kebahagiaan didapat melalui objek dari luar yang sering dianggap dapat memberikan kepuasan (Patanjali dalam Stiles 2002).

Dilihat dari prosedur asana merupakan postur yang nyaman, dilakukan dengan perlahan, meditatif dan disertai pernafasan dalam. Asana dirancang untuk menguatkan setiap bagian tubuh serta memudahkan seseorang untuk mengelola pikiran dan perasaan serta aspek aspek spiritual. Somvir (2008) dan Widyantoro (2004) menyebutkan bahwa beberapa asana dirancang untuk menghormati alam semesta yang telah dianggap membantu aktivitas manusia, yaitu menamai asana dengan nama-nama bagian dari alam semesta seperti seperti gunung (tadasana), pohon (vrksasana), gerakan penghormatan terhadap matahari (surya namaskar), gomukhasana (wajah sapi), gajakarni (gajah), sarpasana (ular), ayam (kukutasana), adho mukha svanasana (anjing). Terdapat literatur yang menyatakan bahwa asana yoga berjumlah 840.000 (Sindhu, 2007). Untuk memudahkan memahami asana agar sesuai tujuan atau kebutuhan orang yang berlatih yoga (Sindhu, 2007). Hal ini dapat dilihat pada tabel yang telah tersedia berikut ini.

Tabel 2.1

Jenis-Jenis Asanas yang dapat diterapkan dalam tataran kehidupan baru (New Normal)

\begin{tabular}{|l|l|l|l|}
\hline No & Jenis Asana & \multicolumn{1}{|c|}{ Manfaat } & \multicolumn{1}{|c|}{ Contoh Asana } \\
\hline 1 & Postur berdiri & $\begin{array}{l}\text { Untuk meningkatkan } \\
\text { stamina, tubuh lebih } \\
\text { seimbang dan stabil }\end{array}$ & $\begin{array}{l}\text { Tadasana (berdiri), padahastasana } \\
\text { (berdiri menekuk ke arah depan), } \\
\text { trikonasana (segitiga), ardha } \\
\text { chandrasana (bulan sabit), } \\
\text { parsvottanasana (menekuk ke depan), } \\
\text { virabhadrasana I, II, III (pejuang), } \\
\text { prasarita padottanasana (menekuk ke } \\
\text { depan dengan kaki terentang), adho } \\
\text { mukha svanasana (anjing), utkasana } \\
\text { (tubuh yang kuat) }\end{array}$ \\
\hline
\end{tabular}




\begin{tabular}{|c|c|c|c|}
\hline 2 & $\begin{array}{l}\text { Postur } \\
\text { Keseimbangan }\end{array}$ & $\begin{array}{l}\text { Otot di kedua sisi stabil, } \\
\text { koordinasi tubuh baik, } \\
\text { pikiran fokus, seimbang otak } \\
\text { kiri dan kanan, memperbaiki } \\
\text { postur tubuh }\end{array}$ & $\begin{array}{l}\text { Vrksasana (pohon), garudasana } \\
\text { (garuda), navasana (perahu) }\end{array}$ \\
\hline 3 & Postur Duduk & $\begin{array}{l}\text { Meningkatkan stabilitas } \\
\text { tubuh, konsentrasi, } \\
\text { melancarkan aliran darah, } \\
\text { mengurangi kelelahan tubuh, } \\
\text { fungsi otak dan saraf } \\
\text { meningkat, tekanan darah } \\
\text { lebih normal, meningkatkan } \\
\text { imunitas tubuh, tidur lebih } \\
\text { mudah, menstabilkan } \\
\text { produksi kelenjar adrenal ke } \\
\text { dalam aliran darah }\end{array}$ & $\begin{array}{l}\text { Sukhasana (bersila), virasana } \\
\text { (pahlawan), ardha padmasana } \\
\text { (setengah teratai), padmasana (teratai } \\
\text { penuh), baddha padmasa- na (postur } \\
\text { teratai terikat), badha konasana (kupu- } \\
\text { kupu), dandasana (ranting), yoga } \\
\text { mudra }\end{array}$ \\
\hline 4 & $\begin{array}{l}\text { Postur Duduk } \\
\text { menekuk ke } \\
\text { arah depan }\end{array}$ & $\begin{array}{l}\text { Tenang, melepaskan ego, } \\
\text { menyatukan tubuh dan } \\
\text { pikiran, menguatkan otot } \\
\text { perut, kaki, tulang punggung, } \\
\text { menstabilkan produksi } \\
\text { kelenjar adrenal ke dalam } \\
\text { aliran darah }\end{array}$ & $\begin{array}{l}\text { Paschimottanasana (postur duduk } \\
\text { menekuk ke arah depan), janu } \\
\text { sirsasana (postur duduk dengan satu } \\
\text { kaki) }\end{array}$ \\
\hline 5 & $\begin{array}{l}\text { Postur } \\
\text { membuka dada }\end{array}$ & $\begin{array}{l}\text { Menguatkan jantung, } \\
\text { menguatkan tubuh bagian } \\
\text { belakang, lengan dan kaki, } \\
\text { tubuh lebih bugar, semangat, } \\
\text { menurunkan stres dan cemas }\end{array}$ & $\begin{array}{l}\text { Bhujangasana (cobra), dhanurasana } \\
\text { (busur), salabhasana (belalang), urdha } \\
\text { mukha dhanurasana (roda, kayang), } \\
\text { matsyasana (ikan) }\end{array}$ \\
\hline 6 & $\begin{array}{l}\text { Postur } \\
\text { melenturkan } \\
\text { sendi pinggul }\end{array}$ & $\begin{array}{l}\text { melepaskan ketegangan di } \\
\text { sendi pinggul, otot hamstring } \\
\text { lentur, mencegah skiatika }\end{array}$ & $\begin{array}{l}\text { Upavistha konasana (duduk kaki } \\
\text { terentang bergerak ke arah depan), } \\
\text { hanumanasana (raja kera), eka pada } \\
\text { rajakapotasana (raja merpati), } \\
\text { omkarasana (kaki bertumpu pada } \\
\text { kepala) }\end{array}$ \\
\hline 7 & $\begin{array}{l}\text { Postur } \\
\text { menguatkan } \\
\text { lengan dan } \\
\text { pergelangan } \\
\text { tangan }\end{array}$ & $\begin{array}{l}\text { Tangan, siku, lengan, bahu, } \\
\text { otot perut } r \text { kuat, } \\
\text { meningkatkan keberanian, } \\
\text { konsentrasi ran } \\
\text { keseimbangan tubuh, tubuh } \\
\text { akan lebih bugar dan segar }\end{array}$ & $\begin{array}{l}\text { Chaturanga dandasana (bertumpu pada } \\
\text { telapak tangan dan kaki), vasisthasana } \\
\text { (pesawat miring), kakasana (gagak), } \\
\text { kukkutasana (ayam jago), } \\
\text { astavakrasana (keseimbangan } 8 \text { sudut) }\end{array}$ \\
\hline 8 & $\begin{array}{l}\text { Postur twist } \\
\text { (memuntir } \\
\text { tulang } \\
\text { punggung }\end{array}$ & $\begin{array}{l}\text { Menyegarkan susunan saraf } \\
\text { pusat, detoks, sendi tulang } \\
\text { punggung lentur, melepaskan } \\
\text { ketegangan di kepala, leher, }\end{array}$ & Marichyasana I, II, III \\
\hline
\end{tabular}




\begin{tabular}{|c|c|c|c|}
\hline & & $\begin{array}{l}\text { bahu, pencernaan meningkat, } \\
\text { tulang punggung dan } \\
\text { pinggang dapat bergerak } \\
\text { nyaman }\end{array}$ & \\
\hline 9 & $\begin{array}{l}\text { Postur inversi } \\
\text { (terbalik) }\end{array}$ & $\begin{array}{l}\text { Relaksasi, memudahkan } \\
\text { darah terpompa ke jantung } \\
\text { dan otak, konsentrasi dan } \\
\text { daya ingat meningkat, tubuh } \\
\text { lebih fit,kelenjar gondok, } \\
\text { sistem saraf pusat aktif }\end{array}$ & $\begin{array}{l}\text { Setu Bandhasana (jembatan), halasana } \\
\text { (bajak), sarvangasana (bertumpu pada } \\
\text { pundak), sirsasana (bertumpu pada } \\
\text { kepala) }\end{array}$ \\
\hline 10 & $\begin{array}{l}\text { Postur } \\
\text { restoratif }\end{array}$ & $\begin{array}{l}\text { Ketenangan } \\
\begin{array}{l}\text { keseimbangan di tubuh, } \\
\text { relaksasi }\end{array}\end{array}$ & $\begin{array}{l}\text { Mudhasana (anak), sputa baddha } \\
\text { konasana (kupu-kupu berbaring), } \\
\text { viparita karani mudra (berbaring } \\
\text { dengan kaki bersandar pada } \\
\text { dinding)savasana (mayat) }\end{array}$ \\
\hline 5 & $\begin{array}{l}\text { Postur } \\
\text { membuka dada }\end{array}$ & $\begin{array}{l}\text { Menguatkan jantung, } \\
\text { menguatkan tubuh bagian } \\
\text { belakang, lengan dan kaki, } \\
\text { tubuh lebih bugar, semangat, } \\
\text { menurunkan stress dan cemas }\end{array}$ & $\begin{array}{l}\text { Bhujjangasana (cobra), dhanurasana } \\
\text { (busur), shalabasana (belalang), urdha } \\
\text { mukha dhanurasana (roda, kayang), } \\
\text { matsyasana (ikan) }\end{array}$ \\
\hline 6 & $\begin{array}{l}\text { Postur } \\
\text { melenturkan } \\
\text { sendi pinggul }\end{array}$ & $\begin{array}{l}\text { melepaskan ketegangan di } \\
\text { sendi pinggul, otot hamstring } \\
\text { lentur, mencegah skiatika }\end{array}$ & $\begin{array}{l}\text { Upavistha konasana (duduk kaki } \\
\text { terentang bergerak ke arah depan), } \\
\text { hanumanasana (raja kera), eka pada } \\
\text { raja kapothasana (raja merpati), } \\
\text { omkarasana (kaki bertumpu pada } \\
\text { kepala) }\end{array}$ \\
\hline 7 & $\begin{array}{l}\text { Postur } \\
\text { menguatkan } \\
\text { lengan dan } \\
\text { pergelangan } \\
\text { tangan }\end{array}$ & $\begin{array}{l}\text { Tangan, siku, lengan, bahu, } \\
\text { otot perut ruat, } \\
\text { meningkatkan keberanian, } \\
\text { konsentrasi r dan } \\
\text { keseimbangan tubuh, tubuh } \\
\text { lebih bugar }\end{array}$ & $\begin{array}{l}\text { Chaturanga dandasana (bertumpu pada } \\
\text { telapak tangan dan kaki), visisthasana } \\
\text { (pesawat miring), kakasana (gagak), } \\
\text { kukkutasana } \\
\text { astavakrasana }\end{array}$ \\
\hline 8 & $\begin{array}{l}\text { Postur twist } \\
\text { (memuntir } \\
\text { tulang } \\
\text { punggung) }\end{array}$ & $\begin{array}{l}\text { Menyegarkan susunan saraf } \\
\text { pusat, detoks, sendi tulang } \\
\text { punggung lentur, melepaskan } \\
\text { ketegangan di kepala, leher, } \\
\text { bahu, pencernaan meningkat, } \\
\text { tulang punggung dan } \\
\text { pinggang dapat bergerak } \\
\text { nyaman. }\end{array}$ & Marichyasana I, II, III \\
\hline 9 & $\begin{array}{l}\text { Postur inversi } \\
\text { (terbalik) }\end{array}$ & $\begin{array}{l}\text { Relaksasi, memudahkan } \\
\text { darah terpompa ke jantung } \\
\text { dan otak, konsentrasi dan }\end{array}$ & $\begin{array}{l}\text { Setu Bandhasana (jembatan), halasana } \\
\text { (bajak), sarvangasana (bertumpu pada } \\
\text { pundak), sirsasana (bertumpu pada }\end{array}$ \\
\hline
\end{tabular}




\begin{tabular}{|l|l|l|l|}
\hline & & $\begin{array}{l}\text { daya ingat meningkat, tubuh } \\
\text { lebih fit, kelenjar gondok, } \\
\text { sistem saraf pusat aktif }\end{array}$ & kepala) \\
\hline 10 & $\begin{array}{l}\text { Postur } \\
\text { restoratif }\end{array}$ & $\begin{array}{l}\text { Ketenangan } \\
\text { keseimbangan di tubuh, } \\
\text { relaksasi }\end{array}$ & $\begin{array}{l}\text { Mudhasana (anak), sputa baddha } \\
\text { konasana (kupu-kupu berbaring dengan } \\
\text { kaki bersandar pada dinding), savasana } \\
\text { (sikap terlentang seperti mayat) }\end{array}$ \\
\hline
\end{tabular}

(Sumber: Sindhu, 2007)

\subsection{Manfaat Yoga Asanas Sebagai Lifestyle Kesehatan di Masa New Normal}

Dimasa New Normal ini, banyak aktivitas yang terjadi yang membuat semua manusia melakukan aktivitasnya seperti sedia kala, namun masih dalam pembatasan kerja. Pembatasan ini, membuat beberapa orang yang masih dalam situasi belum mendapatkan panggilan kerja bahkan sampai terjadinya PHK karyawan oleh perusahaan yang membuat beberapa orang harus melakukan aktivitasnya di rumah. Akibat kebosanan yang melanda di masa ini, beberapa orang berusaha mencari cara untuk melakukan banyak aktivitasnya dengan cara menyibukan dirinya melalui aktivitas menanam bibit tanaman, membersihkan lingkungan bahkan membuat sebuah vlog yoga asanas yang mampu mengisi waktu luang. Ketika waktu tersebut membuat setiap orang mengalami kejenuhan terhadap pikiran, jiwa dan raga manusia itu sendiri. Maka, praktek yoga asanas yang dijadikan tempat untuk menenangkan pikiran manusia agar mendapatkan vibrasi positif dalam setiap melakukan aktivitas. Yoga asana memiliki banyak makna secara luas dan melampaui praktek latihan fisik lainnya karena tidak hanya memiliki pengaruh fisik pada otot dan tulang, melainkan juga pada kesehatan mental, jiwa dan kepribadian spiritual seseorang (Sena, 2018).

Sebagaimana pemahaman orang menganggap bahwa asana hanya bersifat olah jasmani saja dan tidak ada hubungannya dalam memberikan jalan kesadaran spiritual. Persoalan ini menjadikan sebuah kekeliruan terhadap yoga asanas yang semestinya memberikan kesadaran spiritual, tetapi asana hanya dapat dijadikan sebagai tahapan jalan spiritual. Praktik yoga asana dapat membuat pikiran kuat, dapat berkonsentrasi dan mampu menahan rasa sakit yang diderita oleh setiap orang. Dalam melakukan praktik yoga asanas, tentu pikiran dan vitalitas menjadi seimbang serta tubuh menjadi dinamis pada setiap aktivitas yang dilakukan.

Sementara itu, adapula manfaat yang diperoleh dengan melakukan praktik yoga asanas antara lain: 1) Melakukan disiplin dan kewaspadaan yang baik, pada pria, wanita dan anak-anak secara berkala dapat meningkatkan kesehatan dan mengurangi penyakit yang diderita oleh setiap orang. 2) Yoga Asanas dijadikan sebagai metode terbaik untuk menjaga dan mempertahankan 
fleksibilitas tulang belakang serta menghilangkan kelengkungan tulang belakang. Selain itu, dapat memperbaiki penyakit terkait postur tubuh, seperti sakit punggung, nyeri bahu, sendi, kekakuan, dan lain sebagainya. 3) Yoga Asana dapat membangun, membantu dan memperbaiki jaringan otot, menenangkan saraf yang gelisah, menghilangkan kelelahan, mengembalikan energi yang hilang, membantu menjaga tubuh dan pikiran tetap baik. 4) Yoga Asanas sangat mudah dilakukan, tanpa mengeluarkan biaya yang mahal, dapat digunakan sebagai pencegahan, memperbaiki kelainan mental dan fisik atau keduanya, dan tidak memerlukan materi yang banyak untuk melakukannya, cukup dengan matras atau karpet saja. 5) Yoga Asana dapat memberikan energi baru bagi kelenjar endokrin sehingga tubuh menerima bagian penting yang diperlukan untuk fungsi tubuh. 6) Yoga Asanas dapat membentuk kerangka tulang tubuh yang bersifat remaja atau muda, dapat meningkatkan nafsu makan, dan mampu merawat seluruh organ pencernaan. 7) Yoga Asanas dapat membantu mengurangi berat badan secara alami, mengeluarkan lemak dari dalam tubuh, dapat mempertajamkan intelektual, meningkatkan daya ingat dan ketangkasan, serta memperkuat pikiran dan memudahkan untuk berkonsentrasi. Semua kemampuan yang ada di pikiran, jiwa dan mental dapat membentuk sistem energi baru, semangat baru dan merangsang konsentrasi untuk aktif dan dinamis (Sena, 2018:17).

Dengan demikian, praktik yoga asanas yang dijadikan lifestyle pada kesehatan jasmani atau rohani di masa new normal dapat digunakan dari berbagai aktivitas kehidupan sehari-hari sebagai penunjang kesehatan sebelum dan sesudah terjadinya pandemi Covid-19 yang melanda Indonesia. Pemanfaatan yoga asanas mampu membentuk tubuh lebih berstamina, meningkatkan kelenturan, mengencangkan otot, mengurangi rasa ketegangan pada tubuh, melepaskan pikiran yang negatif dari stress, depresi, sampai kekacuan pikiran yang terjadi, memperkuat ketahanan tubuh, mengatur tekanan nafas, dan meningkatkan energi positif baik di dalam diri maupun diluar batas diri manusia. Pergerakan organ tubuh terutama di bagian yoga asanas dijadikan pondasi dalam membangun jalan spiritual. Selain itu, yoga asanas juga dijadikan sebagai media pengobatan secara modern. Temuan ini dikutip dari Yoga Healing oleh Hata Yoga sebagai upaya pencegahan dan pengobatan dari macam penyakit dengan menggunakan cara praktik yoga asanas. Praktik yoga asanas yang dilakukan secara konsentrasi, rileksasi, dan tenang tanpa ketegangan membuat susunan saraf, kelenjar endoktrin berstimulir sesuai fungsi yang ada di dalam tubuh manusia. Meminjam pendapat Yudhiantara sebagaimana dikutip oleh Dwitayasa (2013:81) menyatakan bahwa yoga asanas sangat diminati oleh banyak orang, pada akhirnya yoga asanas digunakan untuk tujuan kesehatan, kebugaran, penyembuahan dari berbagai penyakit, mengendalikan pikiran, jiwa atau mental serta memberikan vibrasi positif bagi vitalitas fisikal dan emosional. 


\section{PENUTUP}

Dalam melakukan aktivitas, tubuh manusia memiliki energi yang mampu meningkatkan kinerja untuk menyeimbangkan tubuh, pikiran dan mental. Sebelum terjadinya masa pandemi Covid-19, setiap perilaku manusia tidak memperdulikan akan lifestyle pada kesehatan dari tubuh, pikiran, makanan atau minuman serta mental manusia itu sendiri. Akan tetapi, di masa new normal ini banyak masyarakat melakukan treatment dengan melakukan praktik yoga asanas sebagai solusi alternatif untuk mengurangi kejenuhan, kebosanan, depresi, stress dan ketidaknyamanan berada di rumah terus sepanjang hari. Melalui situasi tersebut, untuk meningkatkan energi positif, banyak di media sosial yang telah menyebarkan informasi mengenai praktik yoga untuk kesembuhan dari berbagai penyakit termasuk penyakit virus corona yang mampu menetralisir energi atau zat-zat yang kurang baik bagi tubuh, tetapi dapat di netralisir dengan cara beryoga. Sesungguhnya dengan melakukan praktik yoga banyak manfaat yang dapat digunakan dalam kehidupan sehari-hari termasuk pada masa new normal ini. Sementara ini, yoga asanas dapat dilihat dari perspektif ilmu kesehatan terlebih pada masa transisi pandemi Covid-19 yang mampu memberikan manfaat yang luar biasa tanpa harus berkumpul dengan banyak orang. Kehidupan di tengah situasi physical distancing yang memaksa setiap orang untuk menghindari keramaian dan bekerja dari rumah memberikan peluang untuk melaksanakan lifestyle atau gaya hidup sehat secara berbeda. Tentu masih banyak gerakangerakan asanas yang dapat diterapkan dalam pola new normal saat ini. Maka dari itu, yoga asanas dapat dijadikan lifestyle atau gaya hidup sehat yang dapat digunakan dari berbagai situasi seperti masa new normal ini. Penulis berharap para praktisi dan akademisi melakukan penelitian lebih lanjut serta mengeksplorasi manfaat yoga asanas dalam kehidupan yang kompleks.

\section{DAFTAR PUSTAKA}

Anne Ahira. 2010. Pengertian Pola Hidup Sehat. Tersedia dalam http://www.anneahera.com/pengertian-pola-hidup-sehat-8691.htm. Diunduh pada tanggal 5 Agustus 2020.

Anni, Catharina Tri, dkk. 2004. Psikologi Belajar. Semarang: UPT UNNES Press.

Cahyono, Ari. 2012. "Analisis Pengaruh Kepemimpinan, Motivasi, dan Budaya Organisasi terhadap Kinerja Dosen dan Karyawan di Universitas Pawyatan Daha Kediri”, Jurnal Ilmu Manajemen, Revitalisasi Vol. 1 No.1.

Dwitayasa, I. M., 2018. Hidup Sehat Bersama Yoga. Jurnal Yoga Dan Kesehatan, 01(Volume 1, No.1, Maret 2018), pp. 83-91. 
Hanoatubun, S. (Volume 2 Nomor 1 (2020) ). Dampak Covid - 19 Terhadap Perekonomian Indonesia. Journal of Education, Psychology and Counseling, 147-148.

Juniartha, M. G. (2019). Praktik Yoga Sebagai Sosial Religius Membentuk Prilaku Susila. Jurnal Yoga dan Kesehatan IHDN Denpasar Vol 3 Maret 2020, pp. 84-98.

Kurniadi, T .K. (2008). Kalau bisa sehat, kenapa harus sakit. Depok: Puspa Swara

Sena, I. G. (2018). Kinesiologi Yoga Asanas (Kunci Kebahagiaan Tubuh, Pikiran Dan Jiwa). Yoga Dan Kesehatan, 16-17.

Sena, I. G. (5, Agustus 2020). Manfaat Yoga Asana bagi Kesehatan Tubuh, Pikiran, dan Jiwa. From 2018:

https://www.kompasiana.com/widyasena/5a84bb7edcad5b65bd45a3d2/manfaat-yogaasana-bagi-kesehatan-tubuh-pikiran-dan-jiwa

Sindhu, P. (2007). Hidup Sehat dan Seimbang dengan Yoga. Bandung: Qanita

Somvir. (2008). Hidup Sehat dan Bahagia dengan Yoga. Yoga for Health a Voice of Bali edisi 4, April 2008 hlm 4. Bali: Penerbit Yayasan Bali-India Foundation

Stiles, M. (2002). Structural Yoga Therapy: Adapting to The Individual. New Delhi: Goodwill Publishing House

Utama, I.W.B. 2018. Ketika Yoga Sebagai Gaya Hidup. Jurnal Dharmasmrti Vol 18 No 1: Jurnal Ilmu Agama dan Kebudayaan, pp. 16-24.

Widyantoro, Y. 2004. Yoga. Diktat Intensive Classic Yoga di Balance Mind-Body-Soul. Yogyakarta: Tidak Diterbitkan. 